\title{
'Oh God! Why did you let me have this disability?': religion, spirituality and disability in three African countries
}

\section{Background}

Religion and spirituality are some of the central philosophies in coping with disability (Claasens, Shaikh, Swartz 2018). Spirituality is a broader term and may be viewed as an umbrella concept under which one finds religion; the latter is concerned with public participation in a faith community with specific practices and doctrines (Walker, 1992). Phillips (2003) as cited by Marin \& Glover-Graf (2011) perhaps best describes this difference in defining religion as "an extrinsic organized faith system grounded in institutional standards, practices, and core beliefs, while spirituality is intrinsic personal beliefs and practices that can be experienced within or without necessarily belonging to a religious affiliation". Both religion and spirituality have varying influences on the lives and experiences of individuals living with disabilities. These phenomena not only provide the basis for creating meaning in their lives but also offer the much needed platform for reflecting on the 'what would have been' if they weren't living with their disabling condition. Whether or not, the individual is religious, the interrogation of the way spirituality informs conceptions of disability is in most cases inevitable. Overall, spiritual beliefs greatly influence perceptions of people with disabilities, of themselves, others, and the world (Dellassoudas, 2000).

Although, Africans are widely considered to be among some of the most highly religious and spiritual individuals in the world, the extent to which these two concepts influence their perceptions of life remain a matter of debate. The situation is compounded by the multiplicity of religious beliefs and practices found across the wide range of societies on the continent. Conceptualisations of the ancestors play an important role in structuring religious experience and social life--so much so that African kin groups are sometimes described as communities of both the living and the dead (Woodhead, 2002). The discourses of religion and Africa is complex, as scholars explore the effect of colonialism, universalism, secularization or even the multiplicity of faiths on African spirituality.

Religious thinking influences how non-disabled people respond to persons with disabilities. For example, in the context of Nigeria, Etieyibo and Omiegbe (2016) argue that African Traditional Religion influences some of these attitudes and behaviours more than orthodox Christianity and Islam do. They cite violence and murder directed towards people with albinism and the consequent use of body parts in rituals; communal violence against people with mental illness; as well as the recourse to begging by disabled children and adults. Education and counselling can 
help dispel traditional myths and beliefs, particularly with parents of disabled children (Setume 2016).

In the religious context, disability can be seen as a curse or a gift (Claassens et al 2018, 147). For decades, disability theology has explored the ways in which religious traditions have engaged (or failed to engage) with notions of disability and impairment. In discussing the 'disabling theology' for instance, Eiesland (1994) identifies three areas of theology which have been problematic for disability analysis and practically in the lives of disabled people. First, is the conflation of disability with sin, the idea that disability represents punishment for wrongdoing. If God is responsible for everything, then a person's impairment must be evidence of disfavor with God. If this is a dominant interpretation, people with disabilities will be stigmatized, not supported in a religious society (Otieno 2009). The second area associates disability with virtuous suffering, as in the Biblical story of Job. The consequences are to emphasizes passive acceptance of social barriers for the sake of obedience to God. Third, is the perception of persons with disabilities as cases of charity. In many parts of the world, including Africa, the only option for participation in education or other communal activity may be through faith-based organisations (Claassens et al 2018, 148). Even though charity may offer much needed help, it may also result in segregation and demeaning attitudes, rather than justice and equality and participation. Churches may not be inclusive and welcoming (Möller 2012). Theologies of liberation can potentially however offer this transformative potential (Claassens et al 2018,159). Other aspects such as embodiment and healing have also been issues of particular interest since the beginning of Christianity (Avalos 1999; Pilch 2000). Besides, some early church thinkers engaged questions of impairment directly, often within the context of moral understandings of difference (Brock \& Swinton 2012). Questions however, remain about the place of religion and spirituality in lives of disabled persons.

Studies have shown that religion and spirituality are important to persons with disabilities in many societies. Essentially, spiritual beliefs may greatly influence perceptions of people with disabilities, of themselves, others, and the world (Delassoudes, 2000). As with individuals without disabilities, religious teaching for disabled people often defines what people should believe to be true about the world around them, and it prescribes how people should act in accordance with these beliefs (Goldberg, 2006). Even if there is paucity of evidence about the role of religion and/or spirituality in the lives of Africans living with disability, there is ample evidence elsewhere to demonstrate how and why they are quite important. Gallup poll results cited by Vash \& Crew (2003) for instance indicated that $91 \%$ of Americans belong to a religious affiliation and $83 \%$ state that God is important in their lives. Religion and spirituality have also been found to have a perceived impact on disabled persons' impact in dealing with heart disease, cancer, arthritis, 
chronic pain and other conditions (Abraido-Lanza, Vasquez \& Echereria, 2004; Kozak, 2001; Levin 2001; Rippentrop, 2005; Warfield \& Goldstein, 1996). Reviews by Levin (2001) and Salgado 2014) cite numerous studies suggesting that disabled persons who are either spiritual or religious have lower rates of some forms of cancer; lower blood pressure; less heart disease, less depression, and less suicide; and better postsurgical recovery. Spirituality and religion are also an important coping strategy for mental health problems for persons with disabilities (Graf, Marini, Baker \& Buck, 2007; Johnstone, Glass \& Oliver, 2007; Matheis, Tulsky \& Matheis, 2006; Nissim, 2003; Vash \& Crewe, 2003).

The aim of this paper is to draw on 103 qualitative research interviews with persons with disabilities from Kenya, Uganda and Zambia who have experienced success in their lives, in order to explore something of the role which they report that religious belief and religious affiliation has for them. As successful, resilient individuals, they have had to try to come to terms with disability, whether this was congenital, or acquired in childhood or adulthood. As Christians and Muslims, faith has been a source of strength and acceptance, but also sometimes struggle, and the same could be said of the wider faith communities in which they have found themselves.

\section{God and disability: Christian and Islamic perspectives}

As captured during one of the interviews, one respondent said, 'Oh God! Why did you let me have this disability?' This quotation speaks volumes, linking disability to a divine source and in this case blaming the disability on God Himself. Yet treatments of disability from both Biblical and Qur'anic perspectives are more complex and nuanced than this reaction suggests.

\section{Disability in the Bible}

When God appeared to Moses and asked him to lead the Israelites out of Egypt, Moses said to the Lord, "Oh, my Lord, I am not eloquent, either in the past or since you have spoken to your servant, but I am slow of speech and of tongue". For this reason, Moses is customarily regarded as having had a speech impediment. According to Exodus, the Lord replied to Moses. "Who has made man's mouth? Who makes him mute, or deaf, or seeing, or blind? Is it not I, the Lord? Now therefore go, and I will be with your mouth and teach you what you shall speak (Exodus 4: 10-12). This scripture is consistent with the respondent's response above that it is actually God who is responsible for all forms of creation, including all forms of disabilities. 
During his ministry, Jesus performed many miracles, especially on people with disability. This both demonstrates the religious/spiritual connection between God and disability, but also displaces Old Testament accounts in which disability is a punishment for transgression. For example, there is the account of Jesus passed encountering a man who was blind from birth. And his disciples asked him, "Rabbi , who sinned, this man or his parents, that he was born blind?" Jesus answered, "It was not that this man sinned, or his parents, but that the works of God might be displayed in him" (John 9: 1-3). Similarly, Jesus heals the leper in Mark 1, 40, after which many bring disabled people to him for healing, as with the person with paralysis lowered from the roof in Mark 2 1-12. These miracles represent a moment to reveal the healing power of Jesus and to promote worship of God (Mathew 15: 29-31).

The inclusivity of Jesus' mission is highlighted in his words, "When you give a dinner or a banquet, do not invite your friends or your brothers or your relatives or rich neighbors, lest they also invite you in return and you be repaid. But when you give a feast, invite the poor, the crippled, the lame, the blind for they cannot repay you. For you will be repaid at the resurrection of the just (Luke 14: 12-14).

This inclusivity echoes how, throughout the Bible, God uses disabled and disadvantaged people and marginalized people to accomplish his work. As well as Moses Exodus 4: 10-12), Ehud, a left handed man, delivered Israel from its oppressors (Judges 3: 15-26), while it was while Samson was blind that he accomplished God's desired work, destroying the temple and many of the Philistines (Judges 16: 21-30). Leah probably suffered from some sort of eye problem: Genesis 29: 17 describes her as having einei racot, which mean weak eyes, or may imply short-sightedness, lazy eyes, an inability to make eye contact, strangely shaped eyes. However, she was one of the grandmothers of one of the 12 tribes of Israel. Miriam also had leprosy (Num 12: 10-13), but was one of the worshipers of God. Biblical references like this suggest that people with disabilities can equally be used by God, as with non-disabled people.

\section{Disability and the Qur' an}

"Indeed, the worst of living creatures in the sight of Allah are the deaf and dumb who do not use reason. Had Allah known any good in them, He would have made them hear. And if He had made them hear, they would still have turned away, while they were refusing” (Al-Anfal 8: 22-23).

\footnotetext{
${ }^{1}$ Meaning "Teacher" in Hebrew.
} 
This passage is consistent with the earlier Biblical verse that suggests that God is the author of everything, whether good or bad. But it also highlights how many religious texts consider different disabilities differently, particularly those who are intellectually disabled (Imhoff 2017).

In the Qur' an, there are many spiritual promises that are made to believers of the faith about the life hereafter. Unlike in the Bible where instant miracles were reportedly performed on persons with disabilities, in the Qur'an, such people are asked to be patient for a reward thereafter. For example, Ibn "Abbas' ${ }^{2}$ once said to me ('Ata bin Abi Rabah), "Shall I show you a woman of the people of Paradise?" I said, "Yes." He said, "this black lady came to the Prophet (peace be upon him) and said, "I get attacks of epilepsy and my body becomes uncovered; please invoke Allah for me.' The Prophet (peace be upon him) said (to her), "If you wish, be patient and you will have (enter) Paradise; and if you wish, I will invoke Allah to cure you.' She said, 'I will remain patient,' and added, 'but I become uncovered, so please invoke Allah for me that I may not become uncovered.' So he invoked Allah for her." (Sahih Bukhari, Book 7, Volume 70, Hadith 555). Thus disabled people are exorted to be patient and look for Allah's reward: "Those who patiently persevere will truly receive a reward without measure" (Az-Zummar 39: 10). Though not explicitly indicated, the Quaran states that believers should desist form sarcasm and mockery and since people with handicaps and disabilities are usually objects of this, the Qur' an says: "O you who believed, let not people ridicule (another) people; perhaps they may be better than them; nor let women ridicule (another) women; perhaps they may be better than them. And do not carp at one another and do not call each other by offensive nicknames. Wretched is the name of disobedience after (one's) faith. And whoever does not repent-then it is those who are the wrongdoers (AlHujurat 49:11). In the Qur'an, Allah the Almighty has promised us that "with every hardship there is relief," (94:5) and that "no person shall have a burden laid on him greater than he can bear" (2:286). In Surah Yusuf (12: 87), the Qur'an states, "truly no one despairs of Allah's soothing mercy, except those who have no faith."

The Qur'an also offers some affirmative action on persons with disabilities. For example, referring to those who did not join in the fight but remained behind among the Budouins ${ }^{3}$, Allah said : "There is not upon the blind any guilt or upon the lame any guilt or upon the ill any guilt (for remaining behind). And whoever obeys Allah and his messenger-He will admit him to gardens beneath which rivers flow, but whoever turns away, He will punish with a painful punishment (An- Nur 24:61).

\footnotetext{
${ }^{2}$ Abbas was Muhammad's cousin and one of the early Qur'an scholars born in 619 CE (Christian Era)

3 The fighting here refers to the Jihad during the time of Muhammad, the great prophet.
} 
In conclusion, what appears to be common between Judaism, Christianity and Islam is the acknowledgement that God/Allah is sovereign over the fragile and feeble as well as over the adroit and mighty. The Qur'an also seems to agree with the Bible verse that this world is a unique creation of God and this includes disabled people (Psalm 139: 16).

\section{Study methods and areas}

The current paper is part of a three year programme of research that was carried out by research teams from Kenya, Uganda, Zambia and Sierra Leone and UK, that set out to better understand the relationship between disability and development in each country across four domains (health, education, employment and social protection). It was undertaken between April 2015-March 2018. These countries were chosen as they demonstrated a range of socio economic stages of development, characterized by their Human Development Index at the onset of the research, and additionally have all ratified the UN Convention on the Rights of Persons with Disabilities (UN 2006). The research was coordinated by the Leonard Cheshire Disability and Inclusive Development Centre at University College London, with financial support from the UK Economic and Social Research Council (ESRC) and the Department for International Development (DFID).

This paper discusses the findings of the qualitative research conducted in Uganda, Kenya, and Zambia. 4 The aim of this qualitative study was to understand better the experiences of success for disabled people, living in both rural and urban settings. The research question was: "What factors explain success experienced by persons with disabilities". Success, as defined by participants themselves, was variously measured by one's ability to settle in a family and have children, attain a certain level of education, success in gainful employment with government or non-governmental organization, being self-employed, excelling in business, having a leadership position in society or politics. Individuals saw themselves as successful in comparison to neighbours or other family members. For example, a common response in the study was "I was the only member of my family to complete schooling."

Starting from a critical realist epistemology, the study used a life history methodology, to gather the stories of persons with disabilities, starting from childhood, discussing impairment, family, schooling, and adult experiences of work and family. These were semi-structured interviews, using a simple topic guide, allowing follow-up questions. The goal was to gather rich, in-depth

\footnotetext{
4 It should however, be noted that the study results from Sierra Leone were not included in this paper due to
} incomplete transcription and analysis at the time of its writing. 
data, and to be led by what participants themselves said, rather than to explore any pre-existing hypothesis.

Participants were purposefully recruited through disabled people's organisations (DPOs) and non-governmental organisations (primarily Leonard Cheshire Disability). Half were from urban and half from rural areas, and gender balance was aimed for, as well as a range of impairments physical and sensory, although not psychosocial or intellectual disability. Although the target was to interview 40 participants in each country, a total of 105 interviews were held in Uganda, Kenya and Zambia. Those who were not interviewed indicated that they did not have time for the study, despite several call back messages. Two limitation of the study are that participants were not necessarily representative of the wider population of persons with disabilities, and the data is based on self-report.

Ethical issues were of paramount importance for this study. Ethical review was conducted by the Ethics Committee of the University College London and the respective ethics committees in the countries involved in the study. Confidentiality was guaranteed. It was made clear to respondents that participation was voluntary, with no consequences for any services received. Travel expenses and refreshments were paid, and where individuals lost income as a result of participating this was reimbursed, but otherwise there were no inducements to participate. Having been recorded and transcribed, all interview transcripts were anonymized and numbers were substitute for names. Original recordings were destroyed.

The data were thematically analysed using the Framework Analysis Approach (Ritchie \& Spencer 1994). For each country, a series of Excel sheets was created covering a range of variables. Different pages of these charts covered the individual; family; education; employment; attitudes encountered; and external support dimensions of lived experience. These categories were devised based on close reading of the whole body of transcripts. By then charting each transcript across the page, this enabled comparison between the participants. Both authors compared understandings to ensure that the data had been analysed completely and accurately.

\section{Findings}

Socio-economic characteristics of the respondents

The 105 participants had varying forms of disabilities such as hearing loss (7), sight loss (20), albinism (6), restricted growth (5), polio survivor (31) and other forms of mobility impairments 
(36). 66 respondents were male and 39 respondents were female. In respect to the education status of the respondents, 21 indicated that they had failed to complete school, mainly owing to barriers to education. The rest however indicated that they had completed compulsory education-having gone through either special schools or mainstream schools. A total of 16 of the Ugandan participants had degrees while 8 also had postgraduate education. Similarly, in both Kenya and Zambia, 4 respondents had attained at least university degrees while 5 indicated that they also had postgraduate education.

Given that most participants in this study were recruited basing on their economic success, it is not surprising that most of them reported being employed in various sectors of their respective economies. These included; civil service (15), DPOs (22), private businesses (9), self-employed (30), farming (8), professionals (12) and other (4). Only 5 participants indicated that they were economically inactive, either retired or still at school. With respect to family life, 23 of the 31 Kenyan participants, were married or in long term relationships while 22 of the 40 Ugandan participants were married or in long-term relationships. Of the 34 Zambian participants, 26 were married. In addition to having biological children, many of the participants also indicated proudly that they were supporting their siblings and other relatives through paying for their education, medical expenses and looking after their elderly significant others.

\section{Religious belief providing sense of meaning and identity}

In all the three countries studied, the participants embraced religion and spirituality as the embodiment of the set of their personal and behavioral lives by which they are recognized in society. In more ways than one, religion and spirituality gave them that distinct personality-a sense of identity per se.

"Whereas some people see me a disabled person, I'm a child of God. God loves me. God created me, so that makes me part of society like any other person with or without a disability (A Ugandan male participant living with albinism).

For some participants, religion and spirituality defined their self-image, self-esteem, and individuality as disabled persons. For others, it helped them make sense of life, its purpose and destiny. It also helped them deal with stigma and assert their right to co-exist with the rest of society.

"Understanding that I was created by God enables me to say well, 'I have no problem with my disability.' Maybe other people who see me struggle to climb the stairs in a wheelchair do but I don't. And I have no problem saying that I'm disabled because God had a purpose 
in creating me and there is no such a thing as a disability but just different abilities," (A Zambian male physically impaired participant).

But there were also some contradictions as to whether or not religion and spirituality provided a sense of meaning and identity to these disabled individuals. This was evident among the study participants who made it explicitly clear that their connection to the two concepts was actually loose. Reasons to explain their sense of meaning and identity varied greatly: some talked about their own determination to prove to those without disabilities that they can out do them in many spheres of influence; others talked about the family legacy; yet there were also participants who talked about their mindset and ambition as defining factors in shaping their identity and character.

"I certainly know that there is a supreme being called God but it is the hard work and commitment to what I do that enabled me get the university degree that opened many doors to being what I am. Nobody would have recognized me if I hadn't worked hard at school. It is more about me than about God because God has many things to do with following how I behave, what I do on a daily basis and understand what happens around me," (A Zambian female blind participant).

\section{Religious affiliation providing social and material capital}

Religion and spirituality play a number of formal and informal functions in the success of the disabled persons who participated in this study. In addition to providing spiritual guidance and meditation upon their experiences, participants proudly talked about their sense of belonging to varying religious organisations, most of which relate to the underlying reasons for their success in life. For instance, there are regular prayer meetings during which they receive the healing power of God, inspiration and fellowship with other persons-including those without disabilities. In an interview, a Ugandan participant living with a hearing impairment recounted how, attending church with other disabled persons gave her a sense of belonging to the community.

"Having the opportunity to attend Sunday service at the Makerere Pentecostal church for the deaf is one of the best things to happen to me. I meet other disabled

persons and we all feel the presence of the Lord. I also come to know other people who are disabled like me...But even more importantly, I always get the opportunity to thank God for the gift of life and all that I have achieved in life." (A Ugandan, deaf female participant). 
In addition to speaking passionately about their religious beliefs and overall contribution to their success in life, participants also indicated the importance of the religious institutions-notably the church-in the positive change of their fortunes. "The Lilian Foundation of the Netherlandswhich is a Christian organization--paid for my secondary school education," said a Ugandan participant. The same benefactor was also mentioned by a couple of Kenyan participants who attained primary education thanks to its financial and material support. Similarly, the Catholic Church was highlighted as one of the funding religious organisations for disabled persons in Kenya.

"I was sponsored by the Catholic Church at St. Luke's rehabilitation centre, Nakuru town. They paid my fees and provided me with all the basic needs as well as buying me a sewing machine and materials for use. They also provided me with money to start my business (A Kenyan physically impaired female participant).

Other religious organization that contributed to the success of disabled participants in Kenya include the Salvation Army and the World Council of Churches. In addition to providing scholarships to disabled persons at various levels of education, they also served as places of acceptance and unconditional love. Through the activities of these religious bodies, the disabled persons gained much knowledge about the place of God and on each other's strengths and weaknesses. Other benefits that emerged from this association were moral guidance and employment with DPOs founded by or affiliated to religious groups such as those of born again Christians. Being members of faith communities provided social capital, in the way of networks, business partners, potential consumers, and general assistance and advice for individuals with disabilities.

Kenyan participants also highlighted the ecumenical role of the church in the 'internationalization' of the disability network in their country. Working with a host of theological institutions in different parts of the country, the National Council of Churches of Kenya (NCCK) not only provides material benefits to members but also publishes books and provides accommodation to those in need. This was attested to by one participant:

"The NCCK gave me a car and a driver. Its ecumenical disability network is an international program that treats people with disability from the theological point of view. I remember Nancy Iceland. She was the...she wrote the 'disabled God'. Unfortunately, she is dead now." (A Kenyan, visually impaired female participant). 
In Zambia, one participant described his respect for the Catholic Church largely due to the support it provides to persons living with disabilities:

"Although I don't like its approach for adopting a welfare rather than an inclusive approach in what it does, the Catholic Church is not only a powerful institution but also respectable and critical for the success of many disabled persons here in Zambia.”

In all the three countries studied, the participants cited the increasing engagement between the religious groups and their respective DPOs in influencing policy and legislation which are critical for the success of disabled persons. In Uganda for instance, the Uganda National Association of the Deaf (UNAD) was credited for engaging the church in promoting the use of sign language during prayer. In Kenya, the World Council of Churches works with the international disability organisations to promote advocacy for legislative processes. In Zambia, the church has been critical in providing assistive devices to disabled persons, notably wheelchairs.

\section{The 'disabling' effect of religion}

As much as religion is credited for the success of many disabled participants in this study, its 'disabling' effect was also present in some of the stories told during the interviews. For some participants, their association with the church and religious activities often evokes mixed feelings about the type of God they serve and why are disabled. "I'm feeling, Oh God, why did you let me have this disability," said one Kenyan participant whose emotional outburst provides the title of this paper. For others, religion has also served as an impediment to their success by limiting their participation in its activities. Whereas some churches for instance, often discouraged some disabled persons from playing prominent roles in their activities or even taking up significant positions of responsibility among its laity, others are involved in practices that more or less promote stigma among disabled believers-a view explained by a Kenyan participant:

"You go to a church and everybody is looking at you like any other...as is normal. But then when they start praying for the sick, then they think you are sick, when you are not. So you are not very involved, not involved. Yeah, so that just discourages."

Other participants believe that nothing else other than religion-God in particular-should be blamed for the disability condition that sets them apart from the rest of their able-bodied relatives and friends. Those born with hearing impairments for instance, wonder why they have to use sign language for all forms of communication while those born without sight question why their 
Creator denied them the right to see the beauty and glamour of the world-as it was expressed by a Uganda participant who was born without sight.

"There are times when I reflect on my life and ask what I really did to God! How can I fail to see the world, its beauty and my family and friends...why...but why?”

Similarly, a Kenyan participant born without hands explained:

"My neighbours [...] say an evil spirit has been born in this...because they had never seen such a thing. They had seen disabled but maybe just somebody who limps. But not someone, being born actually without hands.”

As a consequence, she was not involved in the church, which she felt discouraged individuals with disabilities. Many respondents born with disability, or acquiring disability in childhood referred to prejudice and discriminatory attitudes experienced by them and their families, often expressed in terms of witchcraft, curse, or the Old Testament idea that the sins of the parents had been visited on the children.

In Zambia, participants highlighted cases of pastors and other leaders who tend to exploit the plight of disabled persons in the name of performing healing miracles. In addition to conniving with unscrupulous able bodied members of their congregation to enact fake physical disabilities for which they proclaim miraculous healing, some of the pastors portray disabled persons as testimony to God's punishment to the 'wicked and spiritually cursed'.

"I really detest these pastors and other preachers who preach that disabled persons are cursed by God because the sins committed by their ancestors. It's even worse when some of them fake miracles of healing using people who are not disabled...It's so disappointing.” (polio survivor, Zambia).

Similar experiences were recounted by other participants to whom the concept of religion only made sense in the context that they only viewed themselves as creations of God but find it difficult to attribute their success in life to the glad tidings of the Almighty.

\section{Religion as reflex}

As well as providing identity and meaning and varying forms of social and material capital, religion and disability also provides a reflex habit to the participants: in form of either thanking or praising God or blaming Him for all that goes wrong in their lives. This fairly unquestioning allegiance stems from their sense or experience of the divine power in their lives. Like their counterparts who live without disabilities, the experiences of those living with disabilities also 
appear to be largely shaped by this background faith in God. In Zambia for instance, a physically disabled male participant who relies on crutch for his mobility simply cited the 'grace of God' for his success while another participant-a woman with restricted growth - indicated that she is a regular church goer to praise God for the gift of life to her and all her achievements. Similar views were echoed by a male participant who was had been disabled at the age of two by polio, who indicated that this sense of a divine power and presence inspired him to take to the pulpit to preach the gospel to all persons-including those living with disabilities.

\section{Discussion}

This paper examines the role of religion and spirituality in the success of disabled persons. It is however, important to bear in mind the different realities in each of the countries studied as we reflect on the meaning and role of religion and spirituality among the participants. First, it is important to recall that the successful disabled persons interviewed have different impairments. Whereas some were born with these impairments or developed them in infancy, others acquired them in later stages of their lives-when they could have probably already gone through varying experiences of belonging to religious groups. And as previous studies have shown, there is no single approach to disability theology because understandings of disability as well as styles of theology vary widely across contexts (Deborah, 2012).

The results show that some of the successful disabled persons interviewed share typical signs of religious people. They believe in the Almighty God, pray (regularly), and attend church, mosques and other places of worship. They also proudly talk of a sense of belonging to a religious community. Although some participants clearly indicated that they owe their loyalty to a religious organisation based on the fact they received material or other forms of support for their education or medical care, others voiced their commitment to religion on account of their desire to worship God and give thanks for the gift of life and probably their success in life.

This study demonstrates that successful disabled people do not merely survive on hand-outs but are individuals who are highly resilient with a 'go-getter' mentality (Shakespeare et al 2019). Even if it is difficult to attribute this mindset to their subscription to a particular religious group, we cannot deny the fact that they attach a lot of importance to having faith or believing in a supreme being greater than themselves. In many ways, religion does-regardless of their economic and even other forms of success-give them the strength to keep going and make sense of the events

in their lives especially when they are swimming against the tide of challenges. Similarly, prayer serves as the spiritual network to communicate with God-especially in their attempt to make sense of why they live with a particular form of impairment. It is also important to note that the 
church and other religious institutions also serve as places of acceptance and unconditional love. All in all, this study has demonstrated that successful disabled persons tend to-just like those without any form of impairment-use religion to satisfy a host of extrinsic and intrinsic motives.

Overall, these findings resonate with those from research elsewhere which dealt with the historical and religious conceptualization of disability. In one such study, Watters (2010) for instance suggests that illness and disability in Islam are not viewed as punishment, but rather as an opportunity to endure suffering in order to receive Allah's grace. The same study also shows that Christianity, on the other hand, views illness and disability as challenges and tests to overcome. In both religions, the study further shows, disability can be seen as a test of faith. Similarly, Brick et al., (2007) also observed that many persons with disabilities may feel that God has abandoned them in their illness or disability, which may subsequently lead to hopelessness, despair, and resentment.

There is often a distinction made between religion (organized faith communities) and spirituality (personal belief). Whereas there is a thin line between 'religiosity' and spirituality, the two philosophies of life are tightly fused with each other. In most cases, successful disabled persons often turn to their spirituality to find meaning and purpose even when they belong to no specific religion or religious organisation. Although we did not clearly focus on issues of spirituality at the design of the study, the participants' experiences with religion highlighting the over-arching view that spirituality gives them the opportunity to engage in varying forms of meditation that serves as the power to overcome their financial, social and emotional setbacks. And as Jude \& Senthil (2002) observed, spirituality has been found to be an important variable when coping with illness especially through relationship with God and their faith community. It is therefore, this combination that renders both religion and spirituality such a vital cog in the 'success and disability' freewheel.

\section{Study Limitations}

The use of purposive sampling to recruit study participants who had experienced success in their lives could have the potential for biases that might have an effect on the results. The findings could also have been affected by the fact that we left it to participants locally to define what success precisely meant to them, rather than using a set of objective external criteria. To offset this limitation, the research team made it clear that economic independence was-more than any other criteria-the key factor in determining success. This largely involved capturing the life stories of persons with disabilities who were thriving on an equal basis with others - not rich, but able to support dependents, often as part of a marriage. 
Further limitation of this study is that it focused on the world's largest religions-Christianity and Islam, because these are too the most dominant religions in the countries studied and have shaped the lives of people in these communities for centuries. The research therefore has less to say about other religions such as African traditional religion or Eastern religions such as Hinduism.

Because this was a relatively small qualitative sample $(n=105)$, the authors are fully aware of the dangers of making broad generalisations of its findings to all persons with disabilities in the countries where it was conducted, let alone across Africa or elsewhere in the world. In this study, we were unable to compare unsuccessful people with disabilities, or non-disabled people with or without equivalent levels of success. We wonder whether persons with disabilities who had not achieved success were less likely to have faith in the divine. Or alternatively, whether they used this faith to reconcile themselves to their difficulties.

\section{Conclusion}

What these faith traditions suggest is that God does not need human might or skill of fitness to accomplish his work but can use disability as well. This may support the multitudes of success stories in this current research, which still conform that what we do as humans is not by our power, might or wisdom but by His grace. Being religious could therefore be a good starting point for persons with disability, to have that solid connection with God as the aforementioned scriptures suggest. Disability studies has failed, to date, to take religion seriously (Imhoff, 2017), even though, for many people in many parts of the world, particularly in the Global South, religion is central to how they make sense of their lives. Beyond this psychological or existential role, religion motivates people and connects people in many societies. Failure to explore the role of religion in the lives of persons with disabilities is therefore a failure of disability studies as a whole. Our data from 103 people with disability in Kenya, Uganda and Zambia, illustrates these many ways in which religious belief and religious networks support and empower people in their lives with impairment, and help them achieve success.

\section{Acknowledgements}

The authors of this paper would wish to acknowledge the individuals who implemented the UCL/Leonard Cheshire Disability "Bridging the Gap: disability and development in Southern Africa” programme funded by UK Economic and Social Research Council and UK Department for International Development. Special thanks go to Professor Nora Groce (UCL) who led the study, and to Maria Kett and Ellie Cole on her team, as well as to Mary Wickenden (now at Institute of Development Studies, University of Sussex) for her support with ethics clearance and advice on 
analysis. Particular thanks also go to Richard Bwalya, Emily Nyariki, Joyce Olenja, and Joseph Simbaya for gathering data and doing preliminary analysis, as well as to Anna Horton (now at McGill University) and Chayan Shanmugaratnam (Norwich Medical School) who gave invaluable help with analysis.

Conflict of interest statement: The authors have no conflict of interest concerning the results reported in this paper.

\section{References}

Abraido-Lanza, A.F., Vasquez, E., \& Echeverria, S.E. (2004). En las manos de dios (in God's hands): Religious and other forms of coping among Latinos with arthritis. Journal of Consulting and Clinical Psychology, 72, 91-102.

Avalos, H. (1999). Health Care and the Rise of Christianity. Peabody, MA: Hendrickson

Johnstone, B., Glass B.A., \& Richard Oliver R. (2007). Religion and disability: Clinical, research and training considerations for rehabilitation professionals. Disability and Rehabilitation, August 2007; 29(15): $1153-1163$

Brock, B. \& Swinton, J. (eds.) (2012). Disability in the Christian Tradition: A Reader. Grand Rapids, MI: Eerdmans.

Claasens L.J., Shaikh, S., Swartz, L. (2018) Engaging disability and religion in the Global South, in Watermeyer, B, McKenzie, J., Swartz, L. (eds) The Palgrave Handbook of Disability and Citizenship in the Global South, Cham CH: Palgrave Mcmillan: 147-164

Creamer, D.B. (2012). Disability Theology. Religious Compass 6(7): 339-347.

Dellassoudas, L. (2000). Church and social integration of disabled people. Greek Orthodox Theological Review, 45, 597-627.

Eiesland, N.L. (1994). The Disabled God: Toward a Liberatory Theology of Disability. Nashville: Abingdon Press.

Etieyibo E, Omiegbe O (2016). Religion, culture and discrimination against persons with disabilities in Nigeria, African Journal of Disability 5, 1, a192.

http://dx.doi 10.4102/ajod.vSi1.1.92 
Imhoff, S. (2017). Why disability studies needs to take religion seriously, Religions 8, 186 doi Goldberg, M. (2006). Kingdom Coming: The Rise of Christian Nationalism, New York: W.W. Norton \& Company.

Graf, N.M., Marini, I., Baker, J., \& Buck, T. (2007). The perceived impact of religious and spiritual beliefs for persons with chronic pain. Rehabilitation Counselling Bulletin, 75 (2), 25-34.

Johnstone, B., Glass, B, A., \& Oliver, R.E. (2007). Religion and disability: Clinical, research and training considerations for rehabilitation professionals. Disability and Rehabilitation, 29, 11531163.

Kozak, D. (2001). Faith eases chronic pain. Prevention, 53 (10), 50.

Levin, J. (2001). God, faith, and healing: Exploring the spirituality-healing connection. Hoboken, NJ: john Wiley.

Marini Irmo \& Glover-Graf, Noreen. (2011). Religiosity and Spirituality Among Persons With Spinal Cord Injury: Attitudes, Beliefs, and Practices. Rehabilitation Counselling Bulletin 54(2): 82-92.

Matheis, E.N., Tulsky, D.S., \& Matheis, R. J. (2006). The relation between spirituality and qualityof-life among individuals with spinal cord injury. Rehabilitation Psychology, 51, 265-271.

Möller, E. (2012) Experiences of people with disabilities in faith communities: a journey, Journal of Religion, Disability \& Health, 16:2, 154171, DOI: 10.1080/15228967.2012.673082

Nissim, E. N. (2003). The impact of spirituality on the quality of life of spinal cord injury patients. Dissertation Abstracts International, 64(02), 972.Otieno, P.A. (2009) Biblical and theological perspectives on disability: implications on the rights of persons with disability in Kenya, Disability Studies Quarterly 29, 4.

Phillips, I. (2003). Infusing spirituality into geriatric health care: Practical applications from the literature. Topics in Geriatric Rehabilitation, 19(4), 249-256.

Pilch, J. (2000). Healing in the New Testament: Insights from Medical and Mediterranean Anthropology. Minneapolis: Fortress Press.

Rippentrop, E.A. (2005). A review of the role of religion and spirituality in chronic pain populations. Rehabilitation Psychology, 50, 278-284. 
Ritchie J, Spencer L (1994) Qualitative data analysis for applied policy research, in A.Bryman and R.G.Burgess (eds) Analyzing Qualitative Data, London: Routledge: 173-194.

Salgado, Ana C. (2014) Review of empirical studies on impact of religion, religiosity and spirituality as protective factors, Journal of Educational Psychology - Propósitos y Representaciones, 2, 1: 141-159

Senzokuhle Doreen Setume (2016) Myths and beliefs about disabilities: implications for educators and counselors, Journal of Disability \& Religion, 20:1-2, 62-

76, DOI: $10.1080 / 23312521.2016 .1152938$

The Bible (ESV) or https://www.openbible.info/topics/disabled

The Qur'an or www.the-faith.com or www.edc.org.kw

Vash, C.L., \& Crewe, N. M. (2003). Pyschology of disability: New York, NY: Springer.

Walker, M.T. (1992). Spirituality: Implications for nursing care. American Association of Rehabilitation Nurses, 48(6), 17-18.

Warfield, R.D., \& Goldstein, M.B. (1996). Spirituality: The key to recovery from alcoholism. Counseling and Values, 40, 196-205.

Watters, E. 2010. Crazy like us: The globalization of the American psyche. New York: FreePress. Woodhead Linda (ed.). (2002). Religions in the Modern World: Traditions and transformations, Routledge, New York. 